\title{
Extending the University for Grass-Roots Development
}

\section{Ronald Clarke}

There are many ways of looking at a university and its role, from both inside and outside. A conservative academic may see his institution as a community of scholars, a sanctuary of the highest learning, to be shared only with a small and select elite. A radical politician (or academic, or student) may see the same institution as a bastion of privilege, outside the mainstream of development and irrelevant to the basic needs of the society. A peasant farmer may also see it as remote from his personal needs and affairs, but at the same time respect it as a place of learning and opportunity to which some of his children or young relations may aspire.

Whatever one's angle of vision it is dangerous to generalise, and there is an unfortunate tendency for some of those who, for the best reasons, wish to give priority for aid to the 'poorest of the poor' to dismiss universities as elitist citadels which have already had too large a share of the cake. While there is undoubtedly some justification for this assessment, it can easily miss the point that universities in the poorer developing countries have a potential far beyond the traditional role of their counterparts in the Western world, and can play a major role in grass-roots development through extension into the community. 1

An interesting contrast may be seen in the conclusions of two conferences held at an interval of ten years on the development of universities in Africa. The 1962 Unesco conference at Tananarive (UNESCO, 1963: 76-7) paid little or no attention to the question of a university's responsibility to the wider community, including in the report only a couple of largely routine references to the need for universities to promote extra-mural and adult education activities.

Ten years later the 1972 conference of the Assocation of African Universities at Accra (Yesufu, 1973) with senior and middle-level academics and administrators from universities all over Africa, emphasised that the commitment

\footnotetext{
I The word 'community' tends to be used imprecisely in these contexts, with connotations ranging from the total population of a country to the subsistence-level inhabitants of a particular village. In this paper I use the term to refer primarily to the common people throughout the country or area concerned, i.e., generally those with little or no formal education; where small local groups are concerned, I refer to education; wher
them as such.
}

of the African university is three-fold: to teaching, to research, and to service for the wider community; and they discussed ways in which the academic community could serve the wider community which would probably sound heretical to most senior academics in Britain. This was of course conference talk rather than actual declaration of specific intent, but at least it demonstrates an attitude which is an essential base for action. And it is by no means all talk. The present reality is in the agriculture and community medicine extension services; in intermediate technology advisory units; in centres for continuing education and extension; in village improvement vacation projects by students; and in many other ways often missed by the casual or less percipient observer of the university and its role in a developing society. Even so, while the university with no community extension services of this kind is perhaps becoming exceptional, it is also true that few universities have any specific plan or stated commitment to community service apart from a general aim of sending their graduating students out to 'serve society', and do little to publicise what is being done in the way of community service, to the extent that one may at times wonder whether the most senior members of some universities themselves know what is going on beyond the campus.

The changes in these directions which are now taking place in the universities in former Britishadministered countries (especially in Africa) have been largely inspired by indigenous political questioning of their role in a new nation, and by the more socially conscious of their own academics. Where inspiration for greater community involvement has come from outside it has come from such areas as North America and China rather than Britain. It was the basically conservative British academic tradition which had been the dominating influence in the development of universities and whatever community involvement they had in the former British colonies; a tradition which, with all its many virtues, tolerated extra-mural departments only in so far as they appeared to maintain "normal academic standards", and viewed the coming of the Open University with deep suspicion.

University extension activities and services to the community can be grouped in various ways. The following may be useful for our present discussion: 1. direct material services; 2 . research and 
consultancy-based services; 3 . educational extension.

\section{Direct material services}

In this first area we may include projects of direct physical or material benefit to small communities which are undertaken mainly by university students, although staff may sometimes be involved. They may be extensive projects undertaken as part of an overall national or university policy (as in the University of Dar es Salaam) ${ }^{2}$, in the form of national service undertaken either before or after undergraduate studies or in the middle of the course (as at one time in Ethiopia at what is now the University of Addis Ababa). Alternatively they may be vacation or short-term projects, for instance as part of a national youth week, which may occur in term time. The work itself may be directly related to the students' course of studies or professional training (e.g., farming activities for those training as agriculturalists, or work in village dispensaries by medical students); or it may be unrelated (e.g., building a community centre, laying water pipes, digging a well).

There is mutual benefit; the villagers see that students are not afraid to work with their hands, or among ordinary people, and at the same time receive some material benefit from the project; the students learn to keep in touch with life at the grass-roots, and have the satisfaction of completing a worthwhile piece of work. This is the theory, but in practice many things can go wrong and much will depend on the attitudes of the students and villagers towards each other and the work they are doing, and on careful planning and co-ordination.

One danger is that the role of the community members may be too passive, in that the students simply come and provide something for nothing and then retire to their citadel of learning. All university extension work should be basically developmental which implies a teaching/learning function whereby the recipients can learn a new skill, and become more self-reliant. There is no reason why work of this kind by students should not have this character, but it demands sensitive direction since people in a local community will only be prepared to learn from those whose skills and knowledge they can respect, especially if they are younger than themselves.

\section{Research-based consultancy services}

Notable examples of research-based consultancy 2 For a detailed discussion of the University of Dar es Court, 1975 and 1976. services can be seen in the Technology Consultancy Centre (TCC) at the University of Science and Technology, Kumasi, Ghana, and in the Industrial Research and Development Unit at the University of Ife, Nigeria.

The growth and activities of the TCC Kumasi have been well documented (Powell, 1975; TCC, Annual Reviews) and the unit has attracted a good deal of international attention and support. Significant features for our discussions are that it involves all the relevant faculties of the university, and (perhaps more controversially) that it has developed production units within the university which actually manufacture and market products in order to demonstrate that they are commercial propositions, hoping that they will then be taken over by a local entrepreneur.

The unit at Ife has a similar purpose, although there is a somewhat different emphasis in the work, and much of the external aid has come from US sources. As in Kumasi, the main concern is with assisting the development of small industries through appropriate technology (as it is called in this case) and the resources of the whole university are available, with many staff involved apart from those specifically employed by the Industrial Research and Development Unit (SIDN; 1975). Rather more than at Kumasi there is an emphasis on the economics and managerial aspects of running a small business, or industry, and the Unit is involved in a study of a large number of entrepreneurial activities of this kind in and around Ile-Ife, collecting and analysing all relevant data to determine whether the concern is likely to be viable.

Also in this area of services which extend the university's research/consultancy function we can include the work of agricultural and medical/ health extension. Virtually all agriculture schools and faculties provide some extension service to their local communities, even if only as essential field practice for their students. Generally, the tendency seems to be for those universities which have been most influenced by American associations to undertake extension/advisory work for local farmers as a university commitment beyond the needs of student training. Thus in West Africa, Njala University College in Sierra Leone, which is probably the most rural institution of its kind in West Africa, has a vigorous and varied programme of extension activities based on several departments of the Faculty of Agriculture, which has included research and marketing of a new baby food (from local benny seed), and 
health and home economics services. ${ }^{3}$ The University of Nigeria at Nsukka, with strong American associations and influence from the land-grant college tradition also has a considerable extension service, as does the University of Ife through its Isoya Rural Development Project (Taiwo Williams, 1975), which has also been supported by a link with the Agricultural Extension and Rural Development Centre at the University of Reading. Again at Ife there is an interesting example of work in this basic research/consultancy area in the field of community health and medicine, where the Drug Research Unit of the Faculty of Pharmacy, which received a grant from the Federal Government to conduct research in herbal medicines, cooperates with local herbalists to examine the local herbs traditionally used as medicines. ${ }^{4}$

Much of this research/consultancy work at grassroots community level also involves a considerable teaching function, far more than in the traditional high-level research/consultancy work of universities. This is particularly obvious in the areas of agricultural and health extension, since the term 'extension' in this context implies not only advice but also instruction so that the recipients can learn a new technique and acquire new knowledge. It is also an important element in the work done by the Kumasi TCC and similar consultancy units, and should indeed be an element in all developmental work.

\section{Educational extension}

The third area is that of educational extension, deriving mainly from the predominant teaching functions of the university, and including those activities in which the primary purpose is to stimulate learning of new skills and new knowledge.

Although many university departments and institutes run their own programmes of public lectures and extension courses, the great majority of this work is done by the institutes and centres of adult and continuing education, several of which have evolved from the old extra-mural departments of pre-independence days. ${ }^{5}$. Much of this provision is beyond the scope of this paper because it is only very indirectly concerned with grass-roots development, and primarily satisfies, or attempts to satisfy, middle-level individual

\footnotetext{
3 Information provided by George B. Goba, Senior Assistant Registrar, Njala University College. I am grateful to several university administrators attending study programmes at Manchester for information relevant to this paper.

4 Information provided by $O$. Lokulo-Sodipe, Deputy Registrar, University of Ife.

5 Only Khartoum (Institute of Extra-Mural Studies) and Fourah Bay College seem to have retained the term 'extramural'
}

ambition through acquisition of paper qualifications. The provision is wide-ranging from degree courses (by correspondence at Lusaka, and evening classes at Lagos) through to GCE or lower-level formal qualifications, and a variety of vocational or general courses.

While some institutes attempt to cater for all apparent needs, some emphasise particular kinds of provision in particular settings. Thus the University of Lagos, in an urban setting, has concentrated through its Centre for Continuing Education on short-term professional courses for special groups of largely urban-based businessmen and professionals in various fields; ${ }^{6}$ while the Centre for Extension Studies of the University of Malawi, in a predominantly rural setting, has concentrated on provision of specially designed continuing education courses by correspondence for middle-level rural development and extension staff who are considered as "intermediate communicators" since they are in direct and regular contact with people at the grass-roots (Clarke, 1974).

Literacy is another area in which a number of university adult education departments have been concerned, and although it is generally felt that universities should not become directly involved in a continuing programme of literacy teaching, there is a role in research, consultancy and training, and occasional assistance with ongoing programmes (perhaps including student involvement), with which the university can and should be involved. ${ }^{7}$ There are indeed convincing arguments for the university's educational extension involvement in grass-roots development to be indirect rather than direct, through study programmes and training courses for the "intermediate communicators" or those who administer the extension, literacy, and community development programmes, etc., in the field.

The question of media is particularly relevant to a university's educational extension provision, since it directly concerns the university's ability to reach people at all levels and in all parts of the country.

Inevitably, it seems, there is a tendency for the university in its various extension services to cater more for the local communities near the campus, largely because of basic problems of physical communication. Extra-mural departments

\footnotetext{
6 See Bown, 1976 for a recent and detailed description of the work of the Lagos CCE, and of other Nigerian universities.

7 See Bown, 1975, for a discussion of the university's role in the promotion of literacy at all levels.
} 
and their successors have done more than most to extend their services throughout the country or area served by the university, and in the past 10 years there have been rapid advances in the use of distance media based on correspondence studies to extend university educational services so that people can study in their own homes or local communities. The successful launching and development of the Open University in Britain has attracted a good deal of attention in developing countries but, although the principle of combined-media studies is excellent, the sophistication and expense of the Open University's operations are far beyond the scope and needs of the poorer developing countries and cannot be simply exported, as some have assumed. In any situation, suitable media need to be identified and effectively used; most study materials need to be written or adapted locally. Much money and time was wasted, especially during the middle and late 1960s, in trying to use television for adult education in Africa, while more basic and readily available media were still being inefficiently employed and other media, with special potential in developing countries, were either ignored or under-used.

On the other side of the world the University of the South Pacific is making imaginative use of a convenient satellite to develop two-way radio communciation betweeen study centres on the islands which come within the university's orbit, and this is clearly the best medium (supported where necessary by printed material) to develop and use for extension education at all levels in this particular situation (Wynne, 1976). In my own experience of the various media (including radio and television) used to provide continuing education during the late 1960 s at Makerere University in Uganda, by far the most effective was the newspaper project, in which correspondence study material in three subjects was published in an 'education supplement' of the national Englishlanguage weekly, which reached many thousands of people beyond those actually enrolled for the correspondence study programme, and had the added advantage of being retainable as reference material. Much of this material could also have been translated and adapted for use in vernacular papers. Yet it seems that only minimal use of the press for educational purposes has been made otherwise by universities in developing countries as a medium for extension education (Clarke, $1968)^{8}$.

8 This pamphlet evaluates the project and also discusses the role of the press in education.
Perhaps the greatest potential for all educational extension work from universities lies in the more effective combined use of suitable media. ${ }^{9}$

\section{Why the university?}

Two main areas of argument which question the nature and extent of the university's role in community affairs, are considered briefly here.

One school of thought argues that this involvement with the common people is inappropriate to a university as an institution of higher learning and scholarship, except in so far as it is beneficial to the student or teacher in his teaching or research. Perhaps a majority of academics throughout the world would hold this view, and possibly also a sizeable proportion of the academics in developing countries, even if they would be less likely to express such views publicly. These are arguments which cannot be lightly brushed aside, since they concern the essential nature of an institution which has been, for many centuries, accepted as a centre of the highest learning. One might reply, first, that community involvement does not, or should not, imply any dilution of the rigorous scholarship, in teaching and research, which should remain at the core of the university's work, only that these intellectual achievements should be communicated to ordinary people, and not maintained as the preserve of a tiny elite; and second, that those who advocate extension and community involvement are by no means necessarily also those who would turn the traditional university into some kind of multi-versity where anyone can come and learn what he likes when and how he pleases.

Another school of argument, rather more pragmatic, contends that much of this involvement in the wider community is inappropriate to a university because other institutions, government departments or voluntary agencies, are better equipped to undertake this work; this, it is argued, may be because the university is mis-directing its highlevel intellectual and physical resources, or because it is less skilled and therefore less able to perform the necessary operations than other agencies. These again are arguments deserving careful consideration, perhaps rather more than insoluble arguments about standards and the essential nature of a university. Undoubtedly there are some activities undertaken by university extension units which could and should be under-

\footnotetext{
9 Unfortunately the Institute of Adult Education in Dar es Salaam is no longer part of the university and therefore technically beyond the scope of this article, but the health education campaigns described in various articles by Bud Hall and others, provide an excellent example of the use of media in a large-scale national project.
} 
taken by government departments: for instance, direct secondary school substitution courses leading to GCE and other school examinations, which should be provided by the Ministry of Education. However there are often good reasons why the university is in the best position to promote these activities, which may not always be explicitly stated, and they include the following:

-its structure is generally less hierarchical and bureaucratic than government ministries, and being thus more flexible it may be able to design and implement a new project more quickly;

-it normally has some degree of neutrality in relation to other organisations which can be very useful where there may be inter-ministerial rivalries, as for instance in the University of Malawi's combined extension studies programme for rural development staff in the ministries of education, agriculture, health and community development; -it is likely to enjoy considerable prestige among the ordinary people, even at times when it is officially out of favour, and this can provide a good foundation for an extension project.

\section{Organisation and administration}

As we have seen, there are many university extension activities taking place, but with rare exceptions they are uncoordinated and underpublicised.

Is this lack of coordination necessarily a bad thing? A heavy bureaucratic hand could easily deflate vigour and enthusiasm in much of the work that is done at present, yet some degree of coordination and planning is surely necessary if the university's potential for grass-roots development is to be more fully realised. It must also imply a commitment by the whole university, and by the people at the top.

I suggest that the following principles should be considered fundamental when a general plan or programme of university extension and community services is being drawn up:

-while the local communities near the campus will inevitably benefit more than others in some ways (e.g., being able to visit a university dispensary or health centre), every effort should be made to provide services for the whole national or regional community in the area which the university serves;

-the whole university should be involved in extension services in one way or another, and these should not be left exclusively to the full-time staff of units tacitly regarded as peripheral to the mainstream work of the university;

-whatever is done should be in close accord with Government policy, and every effort should be made to secure agreement and coordination with community services provided by government and voluntary agencies; wherever possible government officers and other professional people should also be encouraged to become actively involved in the university's programmes, if only to avoid giving the impression that the university has a monopoly of brains and expertise;

-all extension and community services should be essentially developmental in terms of human resources, so that the people in the communities being served are at least given the opportunity to acquire new knowledge and learn new skills, even if the particular extension project is not specifically educational;

-there should be a constant awareness that whatever service is provided for the community it is a process of two-way benefit, and that both students and teachers will be personally improved by their contact with the community, and this not merely in terms of individual research or professional advancement; this awareness should also help to remove any element of condescension in extension provision.

Inspiration and encouragement from the top is essential, and there is unlikely to be any effective and coordinated policy and plan if the ViceChancellor and his senior colleagues are disinterested or pay mere lip service to involvement in community service. The role of the administration in university policy-making and development is a matter for separate discussion, but there is clearly scope for senior members of the central administration to help to coordinate extension services since in various ways they already play an intermediate role between the university, government and the general public. There may be some reluctance on the part of administrators to bcome involved in new organisational problems which will create more work for themselves, but senior administrators have at times been instrumental in getting a new project off the ground, especially where it has involved a unit outside the main faculty structure.

One possibility would be for a senior administrator to be given responsibility for overall coordination, perhaps as secretary to a committee representing all the units in the university directly concerned with aspects of community services and extension provision. Another possibility, where there is already a strong centre or institute for continuing education (or similar unit), is for coordination of all the university's extension activities to be undertaken here, although this would require delicate handling, with much depending on the personality of the director of that 
unit and his relationship with colleagues. It is not difficult to imagine a situation where such an arrangement would prove quite unworkable. Alternatively, where such a unit does not exist, it might be worth considering the creation of a small unit, such as an institute of extension services, through which the university's external work could be channelled and coordinated, but again there would need to be flexibility and scope for individual departments or faculties (such as a medical school on a separate campus) to run their own projects if they are not happy about having them channelled through an institute or centre of this kind, or if they find the director of the institute impossible to work with. ${ }^{10}$

Generally, however, a coordinating committee serviced by a senior administrator who can give a good deal of his time and energy to this work would seem to be the most practical solution to the problem of coordination, especially where there are already strong units engaged in various kinds of extension provision, which would not take kindly to being directed or coordinated by one of themselves. It would also help to suggest more clearly where separate departments of the university could cooperate in certain projects, as for instance the Department of Continuing Education at Ife is now cooperating with the Department of Extension Education and Rural Sociology in the Isoya project referred to earlier, and this is surely the kind of development to be encouraged if the university's potential in these areas is to be more fully realised.

I have not discussed the problems of financing the growth of this work, which would clearly be of some importance. However if the university is seen to be prepared to adjust its priorities and allocate some of its own resources to extension services, it is likely that particular projects will find support from donor agencies including, we may hope, some of those which have so far tended not to associate the university with this kind of developmental role.

\section{References}

Bown, Lalage, 1975, 'Adult Education and the Universities', Overseas Universities No. 22, Inter-University Council, London

Bown, Lalage, 1976, 'Adult Education, the Community and the Nigerian University', paper presented to seminar on Education and the Community in Africa, University of Edinburgh, June

10 In a recent article (1976) Abdelwahid Yousif suggests that each faculty should have its own extension unit, although he recógnised the need for coordination. See also J. Babs Fafunwa's systems model for innovative university education in Yesufu, 1973: 127-8.
Clarke, R. F., 1968, Correspondence Education throughout a National Newspaper, Makerere University College

Clarke, R. F., 1974, 'Part-time Study Programmes for Rural Development Personnel', Convergence Vol. 7 No. 1

Court, David, 1975, 'The Experience of Higher Education in East Africa: the University of Dar es Salaam as a new model', Comparative Education Vol. II No. 3, October

Court, David, 1976, 'East African Higher Education from the Community Standpoint', paper presented to seminar on Education and the Community in Africa, University of Edinburgh, June; also in Higher Education, February, 1977

Powell, J. W., 1975, 'The Work of the Technology Constultancy Centre, Kumasi', Overseas Universities No. 22, Inter-University Council, London

SIDN, 1975, 'University of Ife helps small Nigerian Industry', SIDN Newsletter Vol. 2 No. 2, University of Georgia

Taiwo Williams, S. K., 'Isoya-a rural development project at Ife', Overseas Universities No. 22, Inter-University Council, London

Technology Consultancy Centre, Annual Reviews, Kumasi

UNESCO, 1963, The Development of Higher Education in Africa, Report of the 1962 Conference on the Development of Higher Education in Africa

Wynne, J. G., 1976, 'University Teaching by Satellite', International Review of Education Vol. 22 No. 1

Yesufu, T. M. (ed.), 1973, Creating the African University: emerging issues of the 1970s, Association of African Universities and OUP, Ibadan

Yousif, Abdelwahid, 1976, 'The African University and its Community: the search for a relevant role', Convergence Vol. 9 No. 2 